Mini review

\title{
Recent Progress in Electrochemical Detection of Tumor-Derived Exosomes
}

\section{Xiaohua Ma}

Henan Key Laboratory of Biomolecular Recognition and Sensing, College of Chemistry and Chemical Engineering, Shangqiu Normal University, Shangqiu, Henan 476000, People's Republic of China E-mail: maxhsqnu@aliyun.com

doi: $10.20964 / 2020.08 .101$

Received: 13 April 2020 / Accepted: 8 June 2020 / Published: 10 July 2020

Tumor-derived exosomes are tiny vesicles released from tumor cells to the extracellular environment. The sensitive and selective detection of tumor-derived exosomes is helpful for early diagnosis, clinical monitoring, curative effect evaluation and prognosis judgment of some tumors. In this paper, the detection of tumor-derived exosomes by electrochemical techniques are discussed, mainly including the direct, sandwich-like and magnetoelectric detection.

Keywords: exosomes; electrochemical biosensors; tumor cells; early diagnosis

\section{$\underline{\text { FULL TEXT }}$}

(C) 2020 The Authors. Published by ESG (www.electrochemsci.org). This article is an open access article distributed under the terms and conditions of the Creative Commons Attribution license (http://creativecommons.org/licenses/by/4.0/). 